\title{
Multi-response optimization of postharvest treatments to maintain quality of longan 'Huong Chi' during cold storage
}

\author{
Dinh T. Tran ${ }^{1}$, M. Hertog 3 and B.M. Nicolaï ${ }^{2,3}$ \\ ${ }^{1}$ Faculty of Food Science and Technology, Vietnam National University of Agriculture, Trauquy, Gialam, Hanoi, Vietnam \\ ${ }^{2}$ Flanders Centre of Postharvest Technology, Leuven, Belgium \\ ${ }^{3}$ BIOSYST-MeBioS, Faculty of Bioscience Engineering, KU Leuven, Leuven, Belgium
}

\begin{abstract}
Summary
In this study, a multi-response optimization was applied to determine the optimal postharvest treatment factors for Vietnamese longan 'Huong Chi' throughout the whole storage period. Instrumental measurements were used to analyze quality attributes including soluble solids content, total acidity, weight loss, pericarp color, total phenolics, pericarp browning and microbial disease of the fruit at harvest and after 10, 20, 30, and $37 \mathrm{~d}$ of storage. The optimal postharvest treatment for export fruit, in which no fungicide residue is allowed, consisted of dipping the fruit for $\mathbf{1 0} \mathrm{min}$ in a $\mathbf{7} \mathrm{mM}$ oxalic acid solution and draining them. For fruit for the local market, the optimal treatment consisted of dipping the fruit for $1 \mathrm{~min}$ in a $0.06 \%$ solution of carbendazim, followed by a 10 min dip in a $6.5 \mathrm{mM}$ oxalic acid solution and finally draining. In both cases, fruit should be packed in a polypropylene bag with a relative perforation area of $0.01 \%$ and stored at $4 \pm 1^{\circ} \mathrm{C}$. The overall quality of longan fruit could thus be maintained for $37 \mathrm{~d}$ of storage.
\end{abstract}

\section{Keywords}

Dimocarpus longan, cold storage, fruit quality, response surface methodology

\section{Introduction}

Longan (Dimocarpus longan) is a non-climacteric subtropical fruit, which is widely grown in China and South East Asia. In Vietnam, longan 'Huong Chi', a local speciality in Hung Yen province, is one of the most valuable fruit for domestic and export markets because of its delicious taste and excellent nutritional properties (Tran The Tuc, 2004). It is commonly consumed fresh after removing the peel. However, as longan fruit mature under high temperature and humidity they deteriorate rapidly after harvest due to pericarp browning caused through oxidation of phenolics by polyphenol oxidase (PPO) and peroxidase (POD) (Jiang et al., 2002) and microbial decay (Lin et al., 2001). This limits its expansion in both local and international markets (Duan et al., 2011). Therefore, reducing enzymatic browning and inhibiting the outgrowth of pathogens are important ways to extend storage life and maintain quality of longan fruit.

So far, treatment of longan with sulfur dioxide or related compounds is the most widely and cost-effectively used method to solve these problems (Tongdee, 1994; Xu et al., 1999; Jiang et al., 2002). However, the negative effects of its toxic residues on human health, particularly for asthmatics and sensitive individuals, are well recognized, as well as the

\section{Significance of this study}

What is already known on this subject?

- Longan is an underexploited fruit crop incurring high losses in the local market, having currently a limited export potential. Most data on postharvest treatment of longan fruit are limited to single treatments and single response factors at a time.

What are the new findings?

- This study applied a hierarchical multi-response optimization of postharvest treatments to maintain the postharvest quality of longan fruit during cold storage. The optimal treatment for longan export fruit was dipping of the fruit in oxalic acid solution, then packing them in a $0.011 \%$ perforated polypropylene bag. In this way the overall quality of longan can be maintained for $37 \mathrm{~d}$ at $4^{\circ} \mathrm{C}$.

What is the expected impact on horticulture?

- By providing proper postharvest guidelines to the Vietnamese growers, local economies can be strengthened while providing oversea markets with reliable high-quality fruit and reducing postharvest losses.

flavor taint (Sivakumar et al., 2008).

Alternative procedures to $\mathrm{SO}_{2}$ fumigation of longan fruit have been proposed, such as dipping fruit in 1-10\% (w/v) of organic acid (Sardsud et al., 2003; Koslanund et al., 2008; Whangchai et al., 2006; Apai et al., 2010) or nitric oxide (Duan et al., 2007) with the purpose of lowering pH of the pericarp and acting as antioxidants to inhibit browning. In addition fruit has been treated with fungicides (Onnop et al., 1987; Sardsud et al., 1994; Zhou et al., 1997), chlorine dioxide fumigation (Chomkitichai et al., 2014; Saengnil et al., 2014), hexanal vapor (Thavong et al., 2010), microbial metabolites (Jiang, 1997), plant extracts (Sardsud et al., 1994), and irradiation (Zhuang et al., 1998; McGuire et al., 1998; Hallman 1999) to inhibit microbial growth. Finally, chitosan coating (Jiang and Li, 2001; Shi et al., 2013), and modified atmosphere packing (Liang et al., 1998; Tian et al., 2002; Kaewsuksaeng et al., 2010) have been applied to control water loss and the gas exchange with the environment.

Despite of the fact that longan fruit are extensively consumed in Vietnam and have high potential for export, poor postharvest practices are being applied to longan fruit. For local consumption, fruit are neither cooled nor protected by packaging exposing them to the high surrounding tem- 
perature, thus inducing large postharvest losses. Due to a lack of knowledge, some farmers and retailers preserve the fresh outlook of longan fruit by applying dubious chemicals without knowing their composition, their proper application doses, and possible toxicity. This raises concerns on safety of longan consumption and emphasizes the need for proper postharvest handling practices that are in line with legal requirements. Therefore, our research aimed to optimize the postharvest factors affecting longan fruit quality during cold storage and at the same time to assure treated fruit to comply to safety regulations using a design of experiments (DOE) approach in combination with a multiple response criterion. The current research outcomes will be used to recommend farmers and the horticulture sector to apply better postharvest management to maintain quality and extend shelf life of their produce.

\section{Materials and methods}

\section{Fruit material}

Longan 'Huong Chi' was manually harvested in an orchard in Hung Yen province, Vietnam $\left(20^{\circ} 37^{\prime} 44.4^{\prime \prime} \mathrm{N}\right.$, $\left.106^{\circ} 04^{\prime} 35.9^{\prime \prime} \mathrm{E}\right)$. They were harvested when the pericarp color changed from light yellow to darker yellow and when the rough skin became smoothier. After harvest, fruit were immediately transported under ambient conditions to the laboratory. Fruit were then debranched, sorted for uniform size, color stage, and absence of physical damage and microbial diseases. A random selection of sound fruit was used for the experiment.

TABLE 1. Box-Behnken design (BBD) applied to test the impact of three selected postharvest factors on the postharvest quality of longan fruit. The design consisted of 15 runs, each being a combination of different application levels of the factors oxalic acid concentration $\left(X_{1}\right)$, carbendazim concentration $\left(X_{2}\right)$ and the relative perforation area $\left(X_{3}\right)$. The levels applied are indicated in the relevant columns. The centre point was implemented using three replicate runs (13-15).

\begin{tabular}{|c|c|c|c|}
\hline \multirow[b]{2}{*}{ Run } & \multicolumn{3}{|c|}{ Treatment factors } \\
\hline & $\begin{array}{c}\text { Oxalic acid } \\
(\mathrm{mM}) \\
\left(X_{1}\right)\end{array}$ & $\begin{array}{c}\text { Carbendazim } \\
(\%) \\
\left(X_{2}\right)\end{array}$ & $\begin{array}{c}\text { Relative perforation } \\
\text { area }(\%) \\
\left(X_{3}\right)\end{array}$ \\
\hline 1 & 0 & 0 & 0.008 \\
\hline 2 & 10 & 0 & 0.008 \\
\hline 3 & 0 & 0.1 & 0.008 \\
\hline 4 & 10 & 0.1 & 0.008 \\
\hline 5 & 0 & 0.1 & 0 \\
\hline 6 & 10 & 0.05 & 0 \\
\hline 7 & 0 & 0.05 & 0.016 \\
\hline 8 & 10 & 0.05 & 0.016 \\
\hline 9 & 5 & 0 & 0 \\
\hline 10 & 5 & 0.1 & 0 \\
\hline 11 & 5 & 0 & 0.016 \\
\hline 12 & 5 & 0.1 & 0.016 \\
\hline 13 & 5 & 0.05 & 0.008 \\
\hline 14 & 5 & 0.05 & 0.008 \\
\hline 15 & 5 & 0.05 & 0.008 \\
\hline
\end{tabular}

\section{Response Surface Experimental Design}

In order to determine the potential factors and their working range for optimization in this study, screening experiments were performed during the preceding season with fruit exposed to different treatments. These treatments included dipping for $10 \mathrm{~min}$ in a $2 \mathrm{mM}$ oxalic acid solution, for $5 \mathrm{~min}$ in $\mathrm{HCl} 1.5 \mathrm{M}$, for $1 \mathrm{~min}$ in a solution of $0.05 \%$ carbendazim (CBZ), exposing it for $4 \mathrm{~h}$ to $36 \mathrm{nM} 1-\mathrm{MCP}$, for $2 \mathrm{~h}$ to $36 \mu \mathrm{M}$ hexanal vapor, and then packing in polyethylene and polypropylene bags with relative perforation area ranging from 0 to $0.064 \%$. From the preliminary screening results, three factors having a large influence on the quality of longan were retained for optimization in the current study: (i) oxalic acid, (ii) carbendazim solution, and (iii) the relative perforation area of the polypropylene bags (Tran Thi Dinh and Nguyen Thi Quyen, 2015).

In this study, the response surface methodology (RSM) was applied using a Box-Behnken experimental design (BBD) to determine the optimal postharvest treatment. For these three variables, a design matrix based on 15 trials involving three center points was constructed using JMP software, version 9.0 (SAS Institute, Inc., Cary, NC, USA). The levels of each factor are given in Table 1. The experimental results of the RSM were fitted, for each of the individual storage time points, with the second-order polynomial equation (Equation 1) consisting of linear, quadratic and first order interaction terms by multiple regression.

$Y=\beta_{0}+\sum_{i=1}^{k} \beta_{i} X_{i}+\sum_{i=1}^{k} \beta_{i i} X_{i}^{2}+\sum_{1 \leq i \leq j}^{k} \beta_{i j} X_{i} X_{j}+\varepsilon$

where $Y$ is one of the response variables, $\beta_{o} \beta_{i j} \beta_{i j} \beta_{i j}$ are the regression coefficients for the intercept, linear, quadratic and interaction terms respectively, $X_{i}$ represents the independent variables, $k$ denotes the number of variables and $\varepsilon$ represents the remaining unexplained error. The regression coefficients were estimated by least square regression. The significance of the overall model and of each regression coefficient was evaluated by analysis of variance (ANOVA). Finally, a multi-criterion response surface optimization based on the Derringer's desirability function was employed (Derringer and Suich, 1980; Bezerra et al., 2008). The function transforms the response of each variable into a desirability score (d) ranging between 0 (completely undesirable) and 1 (entirely desirable). The function takes different forms depending on the used optimization criterion: maximization, minimization or attaining a fixed target. The desirability function for maximizing response variables takes the form of Equation 2.

$$
\begin{array}{ll}
d_{i}=0 & y_{i} \leq y_{i, \min } \\
d_{i}=\left[\frac{\left(y_{i}-y_{i, \min }\right)}{\left(y_{i, \max }-y_{i, \min }\right.}\right]^{w i} & y_{i, \min } \leq y_{i} \leq y_{i, \max } \\
d_{i}=1 & y_{i} \geq y_{i, \max }
\end{array}
$$

where $y_{i, \min }$ and $y_{i, \max }$ are the minimum and maximum desired levels of each individual response variable $i$, here the highest and the lowest value of the corresponding quality attribute of the fruit. Responses below $y_{i, \text { min }}$ were assigned a 0 desirability while responses above $y_{i, \max }$ were assigned a desirability of 1 . Between $y_{i, \min }$ and $y_{i, \max }$ the desirability increased linearly by assigning a weight $w_{i}$ of one. The response variables to be optimized were soluble solids content (SSC), total acid- 
ity, color, and total phenolics; those to be minimized were weight loss, browning and microbial disease indexes. The individual desirabilities were then combined for each of the storage time points into a global desirability (D) using the geometric mean (Equation 3).

$$
D=\left(\prod_{i=1}^{n} d_{i}^{r_{i}}\right)^{1 / \sum r_{i}}
$$

where $r_{i}$ denotes the importance given for a particular response. Equal importance was given for all quality attributes by setting all $r_{i}$ values of 1 . By doing so, Equation 3 reduces to a normal geometric mean which is calculated as the root of the product of the $n$ individual desirabilities. In multiple response optimization the geometric instead of the arithmetic mean is used as the individual responses, represented by their desirabilities, are more likely to have a multiplicative instead of an additive effect. The global desirability increases with more quality attributes reaching their desired values. The global desirabilities of the individual storage time points were combined in a higher level desirability function thus extending the optimization to cover the whole storage period. Finally, a search algorithm was applied to find a set of parameters which maximized the overarching global desirability for the whole storage period. This hierarchical multi-response optimization was done using JMP software.

Depending on the experimental design, fruit were treated in different ways, including immersion into solution of carbendazim (CBZ) for $1 \mathrm{~min}$ and/or oxalic acid (Merck Millipore, Darmstadt, Germany) for $10 \mathrm{~min}$. As a control sample, fruit were immersed in plain water instead of chemical solutions. After manually draining and drying in air, 30 fruit with a total weight of about $450 \mathrm{~g}$ were packed in a perforated polypropylene (PP) bag (Xinnai Packing Co., Ltd., Shanghai, China). The PP film typically has a gas transmission rate at $4^{\circ} \mathrm{C}$ of around $294 \mathrm{~cm}^{3} \mathrm{~m}^{-2} \mathrm{~d}^{-1} \mathrm{bar}^{-1}$ for $\mathrm{O}_{2}$ and of $1049 \mathrm{~cm}^{3}$ $\mathrm{m}^{-2} \mathrm{~d}^{-1}$ bar $^{-1}$ for $\mathrm{CO}_{2}$ (calculated after Siracusa et al., 2012). The dimension of a bag was $14 \mathrm{~cm}$ in width, $24 \mathrm{~cm}$ in length and the film thickness of $11 \mu \mathrm{m}$. The perforation holes were made in the lab by mechanically puncturing. The diameter of a hole was $0.3 \mathrm{~mm}$. The bags were heat sealed. Finally, all bags were stored at $4 \pm 1^{\circ} \mathrm{C}$. The relative humidity inside the bags with $0 \%, 0.008 \%$ and $0.016 \%$ relative perforation area, corresponding to 0,2 and 4 holes respectively, were $100 \%$, $95 \pm 1 \%$, and $89 \pm 1 \%$ respectively. Three replicate bags for each observation were taken out for quality inspection at harvest, and after 10, 20, 30 and $37 \mathrm{~d}$ of storage.

\section{Quality assessment}

1. Soluble solids content and weight loss. A set of 30 fruit per replicate were randomly selected for SSC determination. After removing the peel and seed, the flesh was pressed and the juice was used to determine SSC using a digital refractometer (Atago Co., Ltd., Tokyo, Japan). The results were then averaged and expressed as a percentage (\%).

Weight loss $(\Delta \mathrm{M}$ in \%) was monitored at each time interval using an electronic balance. It was calculated by using mass obtained at harvest $\left(M_{0}\right)$ and mass obtained at a certain storage time (M).

$$
\Delta M=\frac{M_{0}-M}{M_{0}}
$$

2. Total acidity. Total acidity was determined from a 30-fruit composite sample by titrating $10 \mathrm{~mL}$ of the longan juice with $0.1 \mathrm{~N} \mathrm{NaOH}$ (Merck Millipore, Darmstadt, Germany) in the presence of phenolphtalein as an indicator until pink color end point was achieved. The results were then averaged and expressed in $g$ tartaric acid $\mathrm{L}^{-1}$ (Li et al., 2009).

3. Pericarp color. The fruit pericarp color was measured at two random positions around the equator of each longan using a Minolta CR-300 colorimeter (Minolta Camera Co., Ltd., Osaka, Japan), and expressed in the CIELAB color space. The pericarp color was characterized by hue $\left(^{\circ}\right)$.

$$
\text { Hue }=\arctan \left(\frac{b^{*}}{a^{*}}\right)
$$

4. Total phenolics. Total phenolics were determined by using the Folin-Ciocalteu reagent (Singleton and Rossi, 1965) with some minor modifications. Briefly, $0.5 \mathrm{~g}$ of freeze-dried pericarp was extracted with $10 \mathrm{~mL}$ methanol in a falcon tube for $1 \mathrm{~h}$ at $70^{\circ} \mathrm{C}$, then cooled down to ambient temperature, followed by centrifugation at $3642 \mathrm{~g}$ for $10 \mathrm{~min}$ at $4^{\circ} \mathrm{C}$. Afterward, the extract was diluted with distilled water. Then, $1 \mathrm{~mL}$ of supernatent was mixed with $5 \mathrm{~mL}$ of $10 \%$ Folin-Ciocalteu reagent for $5 \mathrm{~min}$ before $4 \mathrm{~mL}$ of $7.5 \% \mathrm{Na}_{2} \mathrm{CO}_{3}$ was added. The mixture was incubated at ambient temperature for $1 \mathrm{~h}$ in the dark. Finally, absorbance of the test portion was measured at $765 \mathrm{~nm}$ using a UV-VIS spectrophotometer (Shimad$\mathrm{zu}$, Japan). The total phenolics were determined from the linear equation of a standard curve prepared with gallic acid and expressed as \% dry weight (DW). All chemicals were of analytical grade and bought from Merck Millipore, Darmstadt, Germany.

5. Pericarp browning and microbial disease. Pericarp browning and microbial disease index were assessed by using the scale in Table 2 described by Khan et al. (2012). The browning/disease index was calculated using the following formula:

\section{$\sum$ browning/disease rating $\times \%$ of fruits within each class}

Fruit having a browning/disease index above 3.0 were rated as unacceptable for visual marketing quality.

\section{Results and discussion}

\section{Effect of postharvest treatments on quality attributes of longan during storage}

The change of SSC during storage is indicated in Figure 1A. Its decrease was more profound with storage time and to a lesser extent with treatment condition. At harvest, the SSC was $17.8 \%$. After $37 \mathrm{~d}$ it reached $15.5 \%$ for treatments No. $9,10,11$. The decrease in SSC during storage can be ex-

TABLE 2. Scale for browning and microbial disease assessment.

\begin{tabular}{ll}
\hline Pericarp browning index & Microbial disease index \\
\hline $1=$ no browning index & $1=$ no fruit infected \\
$2=$ slight browning & $2 \geq 0-5 \%$ infected fruit \\
$3 \leq 25 \%$ browning & $3 \geq 5 \%-10 \%$ infected fruit \\
$4=25 \%-50 \%$ browning & $4 \geq 10 \%-25 \%$ infected fruit \\
$5 \geq 50 \%-75 \%$ browning & $5 \geq 25 \%-50 \%$ infected fruit \\
$6 \geq 75 \%$ browning & $6 \geq 50 \%$ infected fruit \\
\hline
\end{tabular}


plained by the fact that longan is a non-climacteric fruit as no postharvest ripening occurs (Huang et al., 1995) while substrates such as sugars, organic acids, and other intermediate metabolites still enter the Krebs cycle to gain energy for the maintenance processes (Taiz and Zeiger, 2002).

Similar to SSC, total acidity also declined in time. The longer the storage period, the more acidity was reduced by metabolic activity with the acidity retention depending on the treatment. There was no significant difference in acidity between control (No. 1) and treated fruit No. 3, 5-7 after $10 \mathrm{~d}$ of storage (about $0.61 \mathrm{~g} \mathrm{~L}^{-1}$ ). Nonetheless, the acidity of the control fruit clearly decreased after $20 \mathrm{~d}$ and had the lowest value after $37 \mathrm{~d}$, followed by fruit without acid dipping (No. 7, 3). It seemed that dipping fruit in acid solution had a positive effect on maintaining acidity. Our results are in accordance with Apai et al. (2008) showing that longan dipped in a $1 \%$ citric acid solution gave the highest acidity retention compared to control fruit or fruit coated with chitosan. It was also observed that fruit packed in non-perforated bags (No. 5, 6, 10) had a higher acidity compared to fruit in other treatments from $20 \mathrm{~d}$ onward (Figure 1B). This may be due to a reduction of the respiratory activity of the fruit due to reduced oxygen and/or increased carbon dioxide concentration inside the package, and, hence, limited consumption of organic acids in the TCA cycle (Etienne et al., 2013).
Weight loss varied among treatments (Figure 1C). The control fruit (No. 1) had highest value, followed by No. 7, 8, 11,12 (about $0.8 \%$ after $37 \mathrm{~d}$ of storage). The lowest value was obtained in treatments No. 13-15 (about 0.4\%). It can be deduced that untreated fruit and a high level of perforation had a negative effect on weight loss.

During storage the natural yellowish color of longan pericarp turned brown as was evident from a decreased hue value as function of time and treatment (Figure 2A). There was a clear trend in the decrease of hue: whether or not fruit were dipped in acid and antimicrobial solution, when they were packed in a non-perforated bag the hue value decreased dramatically during storage (No. 5, 6, 9, 10), followed by the control fruit. The treatments maintaining high hue values were No. 2, 4, 8, 12, and the center points of the designed cubes. Our findings are well aligned with Whangchai et al. (2006) and Boonin et al. (2006). They proved that application of oxalic acid could inhibit the activity of PPO and POD, resulting in a reduced oxidation of polyphenols in longan pericarp. In addition, oxalic acid was reported as the most potent browning inhibitor among a number of carboxylic acids on freshcut banana and apple (Son et al., 2001; Yoruk and Marshall, 2003) and fresh-cut mangosteens (Suttirak and Manurakchinakorn, 2010).
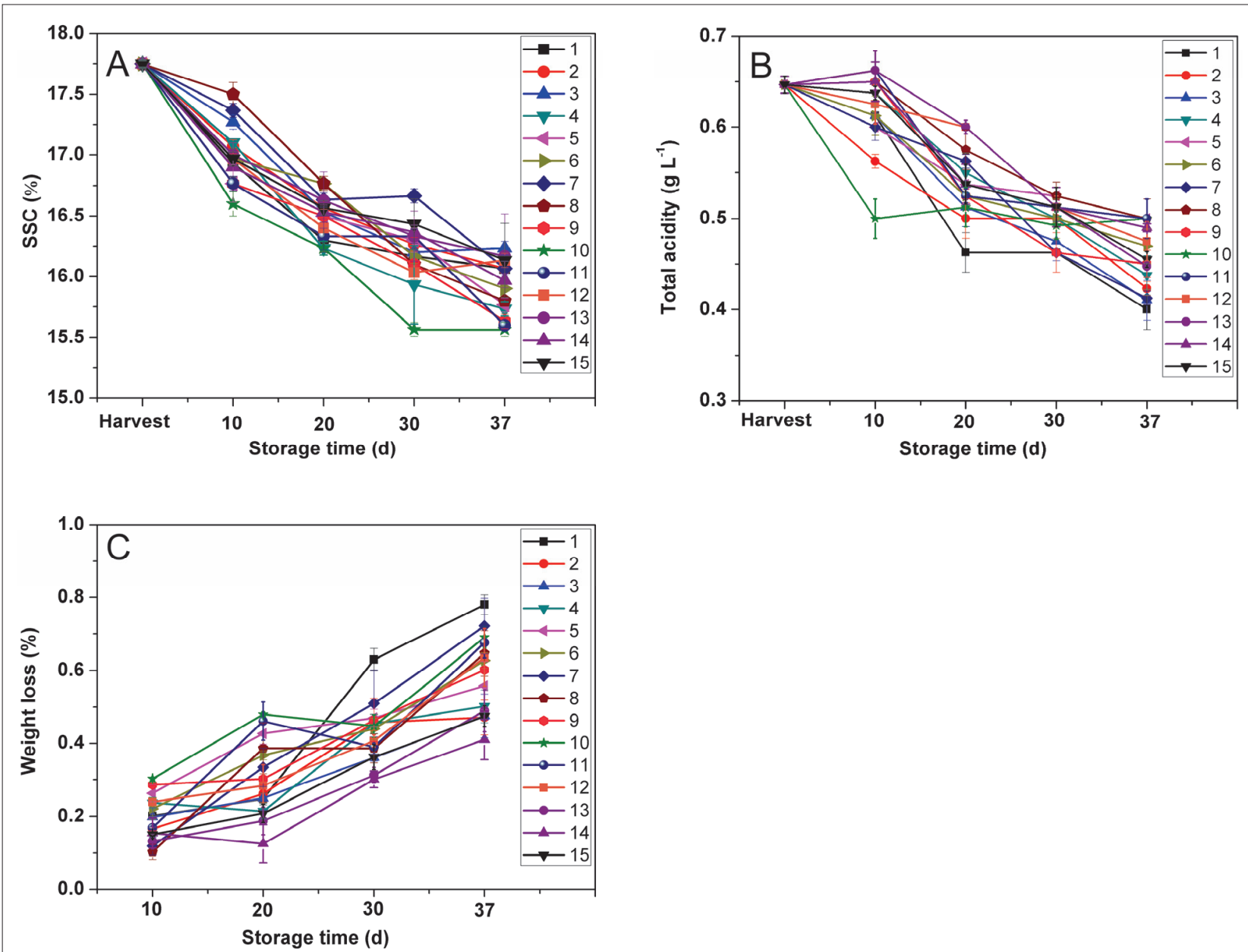

Figure 1. A) Change in soluble solids content (\%) of longan fruit during storage time at $4 \pm 1^{\circ} \mathrm{C}$, error bars represent the standard deviation of the mean of 6 replicates. B) Change in total acidity $\left(\mathrm{g} \mathrm{L}^{-1}\right)$, error bars represent the standard deviation of the mean of three replicates. C) Change in weight loss (\%), error bars represent the standard deviation of the mean of three replicates. Treatments 1-15 were combinations of oxalic acid solution, carbendazim solution, and relative perforation area of the bag, as indicated in Table 1. 


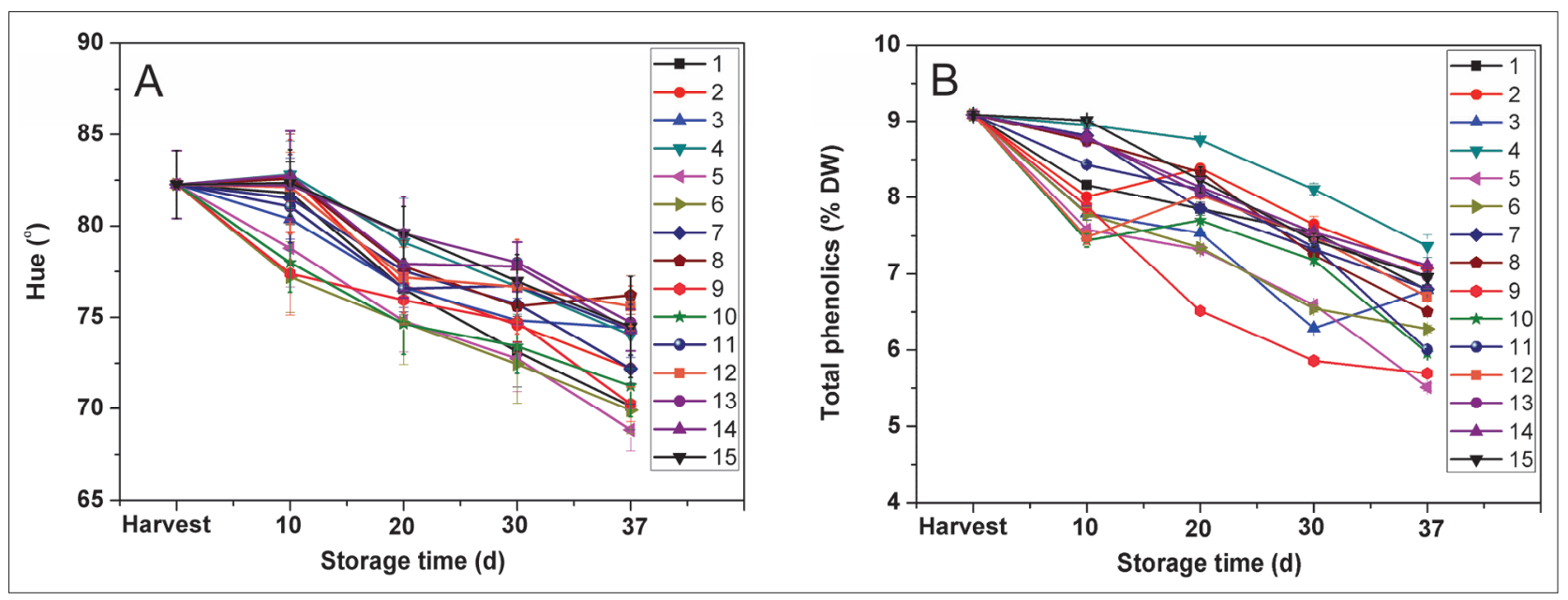

FIGURE 2. A) Color change expressed as hue $\left({ }^{\circ}\right)$ of longan fruit pericarp during storage at $4 \pm 1^{\circ} \mathrm{C}$, error bars represent the standard deviation of the mean of 20 replicates. B) Change in total phenolics (\% DW) of longan pericarp, error bars represent the standard deviation of the mean of three replicates. Treatments 1-15 were combinations of oxalic acid solution, carbendazim solution, and relative perforation area of the bag, as indicated in Table 1.
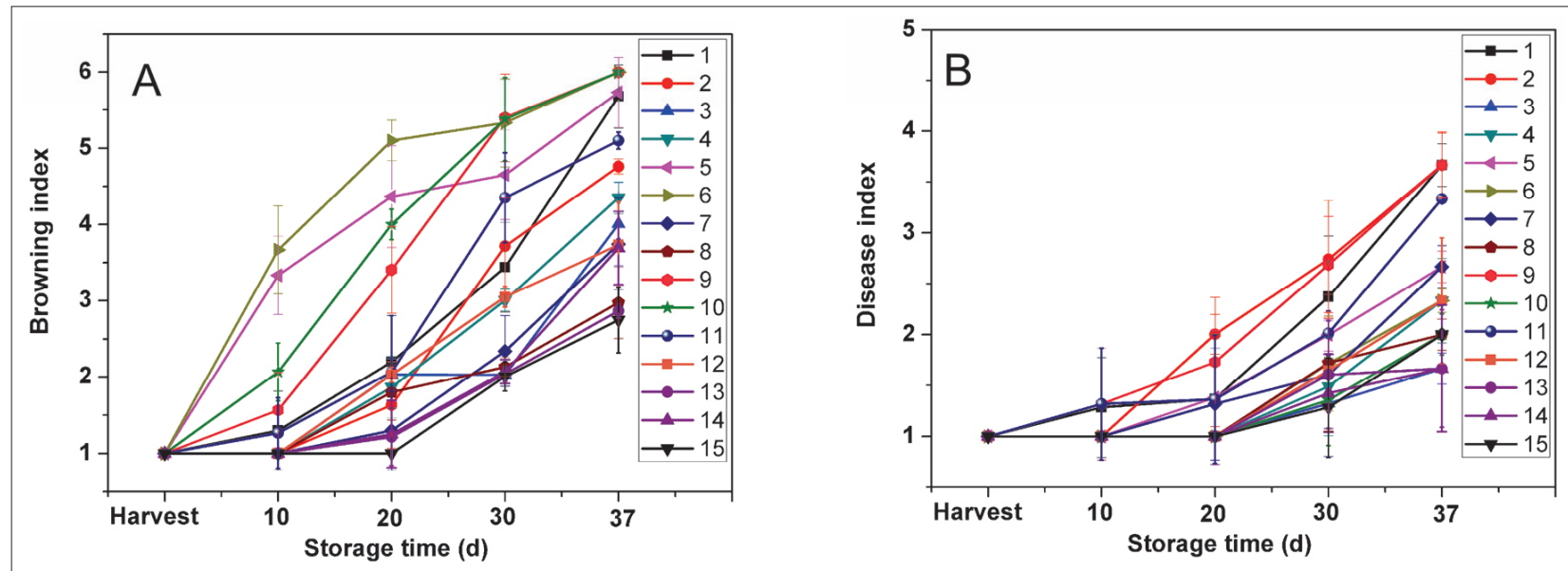

FIGURE 3. A) Change in browning index of longan fruit pericarp during storage at $4 \pm 1^{\circ} \mathrm{C}$, error bars represent the standard deviation of the mean of three replicates. B) Change in disease index, error bars represent the standard deviation of the mean of three replicates. Treatments 1-15 were combinations of oxalic acid solution, carbendazim solution, and relative perforation area of the bag, as indicated in Table 1.

The color of the fruit is not only reflected by the hue value but also by the amount of phenolic compounds present in the pericarp. From Figure $2 \mathrm{~B}$ it is observed that the total phenolic level (expressed as \% DB) was reciprocal to time. Again, treatments No. 5, 6, 9, 10 had the highest degradation of polyphenol due to lack of perforation. The fruit dipped in oxalic acid solution and packed in a suitable perforation bag had better retention on total phenolic content (No. 2, 4, $8,12-15)$. This finding once more confirmed the important role of bag perforation and acid dipping in maintaining color of the pericarp.

The browning index, another means to reflect the color change of the pericarp, showed that at harvest the fruit showed no incidence of browning. However, the longer the storage life the higher the browning index. After $20 \mathrm{~d}$ most of the treatments had a score below 2, while treatments No. 5 , 6, 9 and 10 already increased to above 3.0, indicating a significant loss of commercial value. After $37 \mathrm{~d}$, only treatments No. 8, 13, and 15 still had scores below 3.0 (Figure 3A).

During storage, fruit might be attacked by pathogens which could have been either present on the pericarp before harvest or transmitted from the storage environment. The result of microbial infections developing with time is given in Figure 3B. Those treatments in which fruit were dipped in acid and fungicide solutions and then packed in perforation bag remained free from pathological decay during the first $20 \mathrm{~d}$ of storage. These treatments gave a better inhibitory effect on microbial growth as compared to the treatment of longan 'Daw' with oxalic acid 5\%, followed by ozone fumigation as done by Whangchai et al. (2006). For fruit without fungicide dipping or with fungicide dipping but packed in non-perforated bag the incidence of decay started to appear after $10 \mathrm{~d}$ and continued to develop. After $37 \mathrm{~d}$, the worst treatments (No. 1, 2, 9, and 11) caused fruit to be totally spoiled due to microbial growth. It should be noted that in this study fruit without dipping sometimes had less disease development as compared to dipped fruit. This can be explained from normal biological variation in the level of latent infection at harvest. While some control fruit might have had a low degree of latent infection, some fungicide treated fruit might have had to deal with a much higher degree of latent infection, as a result of which pathogen decay could not be totally prevented. By combining the proper chemical treatment with perforated bags a very effective overall control of 
the biological decay was obtained. In non-perforated bags, even fruit treated with fungicide solution did not show much inhibition of the pathogens.

\section{Hierarchical multi-response optimization of} postharvest treatment factors to maintain fruit quality

In order to assess the significance of the treatment factors on quality attributes and to gain the desirability scores for every moment during storage, the experimental results were fitted to the linear model from Equation 1. The fitting results for each response variable for each storage time are shown as supporting information (Table S1). In general, the models were significant for all quality attributes ( $\mathrm{p}$-value $<0.0001$ ) except for the microbial disease index in the first $10 \mathrm{~d}$ of storage. This is plausible as the low storage temperature $\left( \pm 4^{\circ} \mathrm{C}\right)$ slowed down microbial growth under all conditions, minimizing differences between the treatment combi- nations. Treatment with oxalic acid solution had a significant effect on the remaining acidity, SSC and total phenolics already from $10 \mathrm{~d}$ onward, while oxalic acid $\left(X_{1}\right)$ became significant for hue after $20 \mathrm{~d}$, and after $30 \mathrm{~d}$ for all quality attributes. The relative perforation level of the bag $\left(X_{3}\right)$ did have a significant effect on almost all quality attributes except for weight loss and pathological decay. A fungicide treatment $\left(X_{2}\right)$ immediately had a profound effect on inhibiting microorganisms after $10 \mathrm{~d}$ of storage. Although fruit without fungicide treatment had a higher index than treated fruit, they both had a score below 3 , corresponding to less than $5-10 \%$ of the fruit area being infected after $30 \mathrm{~d}$ of storage. From this it can be concluded that if one needs to store fruit longer than $30 \mathrm{~d}$ for the regional market, a fungicide treatment could help to prolong the shelf life; otherwise, dipping fruit in oxalic acid solution and packing in a suitable perforated bag allowed keeping fruit fresh up to $30 \mathrm{~d}$.
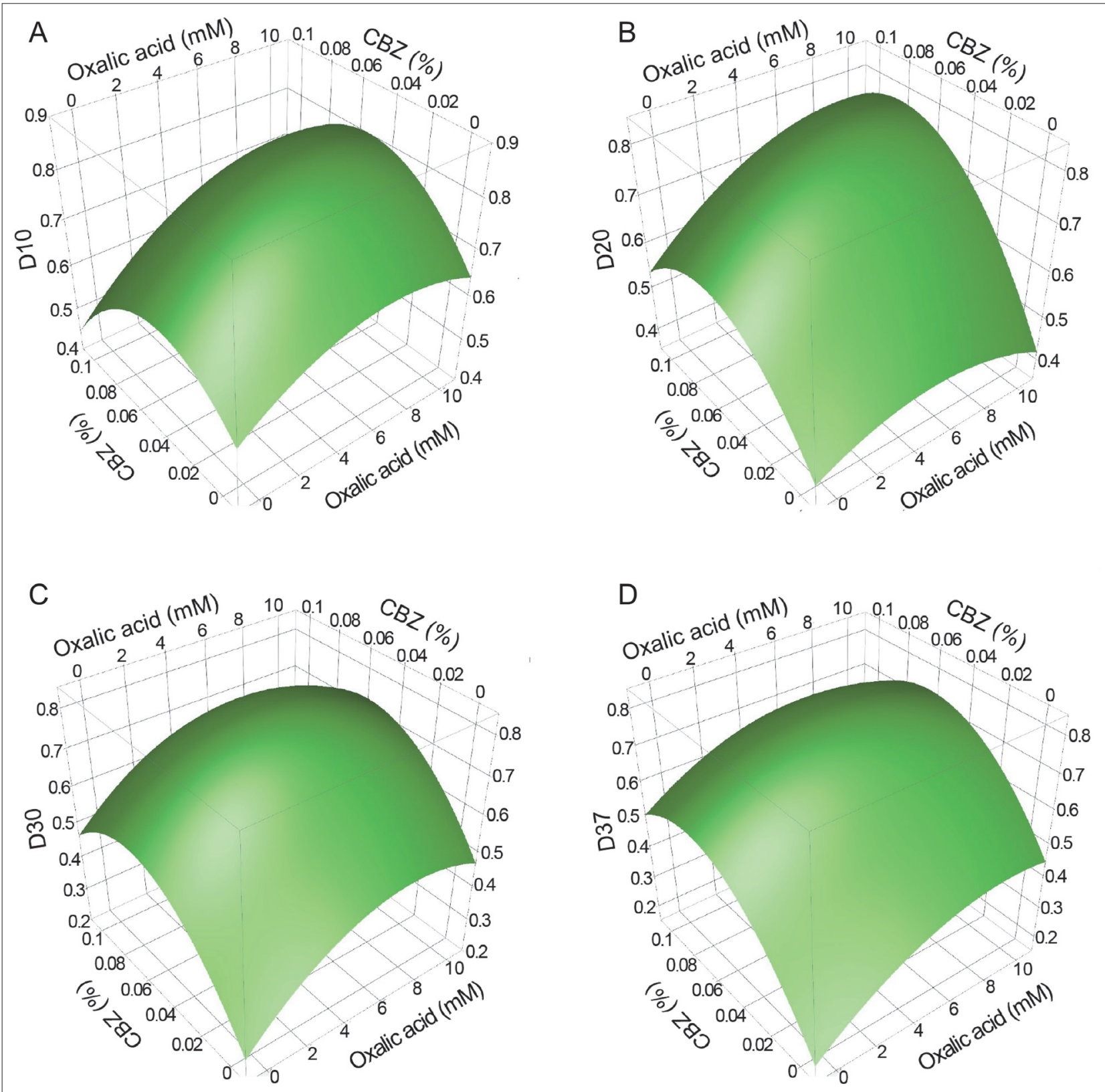

FiguRE 4. Three-dimensional response surface showing the effect of oxalic acid $\left(X_{1}\right)$ vs. carbendazim level (CBZ) $\left(X_{2}\right)$ on the global desirability function obtained after 10 days of storage (panel A), after 20 days of storage (panel B), after 30 days of storage (panel C), and after 37 days of storage (panel D). 
TABLE 3. Coefficients of the second order models for the global desirability per storage time point. (The desirabilities can be reconstructed by combining the tabulated coefficients with the actual values of the experimental factors from Table 1 , following the second order polynomial from Equation 1).

\begin{tabular}{lcccc}
\hline Components & $\begin{array}{c}\text { Desirability after } 10 \mathrm{~d} \\
\left(\mathrm{D}_{10}\right)\end{array}$ & $\begin{array}{c}\text { Desirability after } 20 \mathrm{~d} \\
\left(\mathrm{D}_{20}\right)\end{array}$ & $\begin{array}{c}\text { Desirability after } 30 \mathrm{~d} \\
\left(\mathrm{D}_{30}\right)\end{array}$ & $\begin{array}{c}\text { Desirability after } 37 \mathrm{~d} \\
\left(\mathrm{D}_{37}\right)\end{array}$ \\
\hline Intercept & 0.59 & 0.48 & 0.47 & 0.42 \\
Oxalic acid $\left(X_{1}\right)$ & 0.01 & 0.008 & 0.01 & 0.014 \\
CBZ $\left(X_{2}\right)$ & -0.21 & 1.46 & 1.41 & 1.79 \\
Relative perforation area $\left(X_{3}\right)$ & 16.16 & 14.53 & 16.13 & 14.93 \\
$X_{1}{ }^{2}$ & -0.002 & -0.002 & -0.003 & -0.003 \\
$X_{1} \times X_{2}$ & 0.10 & 0.14 & -0.04 & -0.07 \\
$X_{2}{ }^{2}$ & -39.5 & -39.1 & -51.2 & -50.9 \\
$X_{1} \times X_{3}$ & 0.73 & 0.31 & 1.04 & 0.46 \\
$X_{2} \times X_{3}$ & -18.73 & 132.3 & -28.52 & 58.95 \\
$X_{3}{ }^{2}$ & -2455 & -2447 & -2466 & -2772 \\
\hline Model $(p$-value $)$ & $<0.0001$ & $<0.0001$ & $<0.0001$ & $<0.0001$ \\
\hline
\end{tabular}

Figure 4 provides a graphical inspection of the global desirability function. Although these representations are only partial, since in each case one of the three main factors was kept constant at its optimal value, their optimum regions were similar for each storage time. However, the global desirability decreased over storage time from 0.8 after 10 days down to 0.7 after 37 days. This is due to the decrease of quality attribute as function of storage time.

The global desirabilities per storage time point were obtained by combining the desirability scores for all quality attributes at each storage time. The main factors oxalic acid concentration $\left(X_{1}\right)$, carbendazim concentration $\left(X_{2}\right)$, and relative perforated area $\left(X_{3}\right)$, their interactions, and quadratic

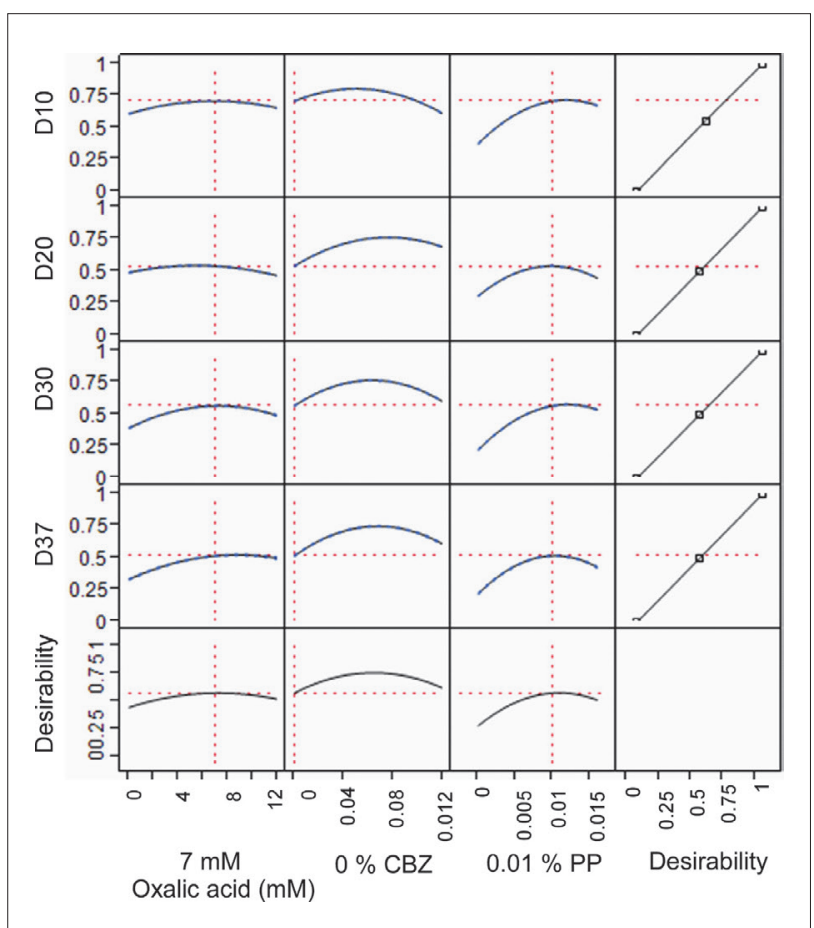

FIGURE 5. Profiler showing the optimal postharvest treatments of longan fruit without fungicide dipping (CBZ was set to $0 \%$ ). The optimal values for the postharvest treatment factors were determined by maximizing the higher level desirability function which is a combination of the global desirabilities of the individual storage time point. terms significantly contributed to the desirability after $10 \mathrm{~d}$, $20 \mathrm{~d}, 30 \mathrm{~d}$ and $37 \mathrm{~d}$ of storage with their regression coefficients provided in Table 3.

The global desirabilities per time point served as new variables to determine the optimal postharvest treatment considering the whole storage period as shown in Figures 5 and 6. The first four rows of graphs depict the global desirability per time point (D10, D20, D30 and D37) as a function of the experimental main factors (the first three columns). The slope and curvilinearity reflects the dependencies of the desirabilities on these factors. The graphs however only represent a single cross section valid for the current selected combination of main factor values as the exact shapes will

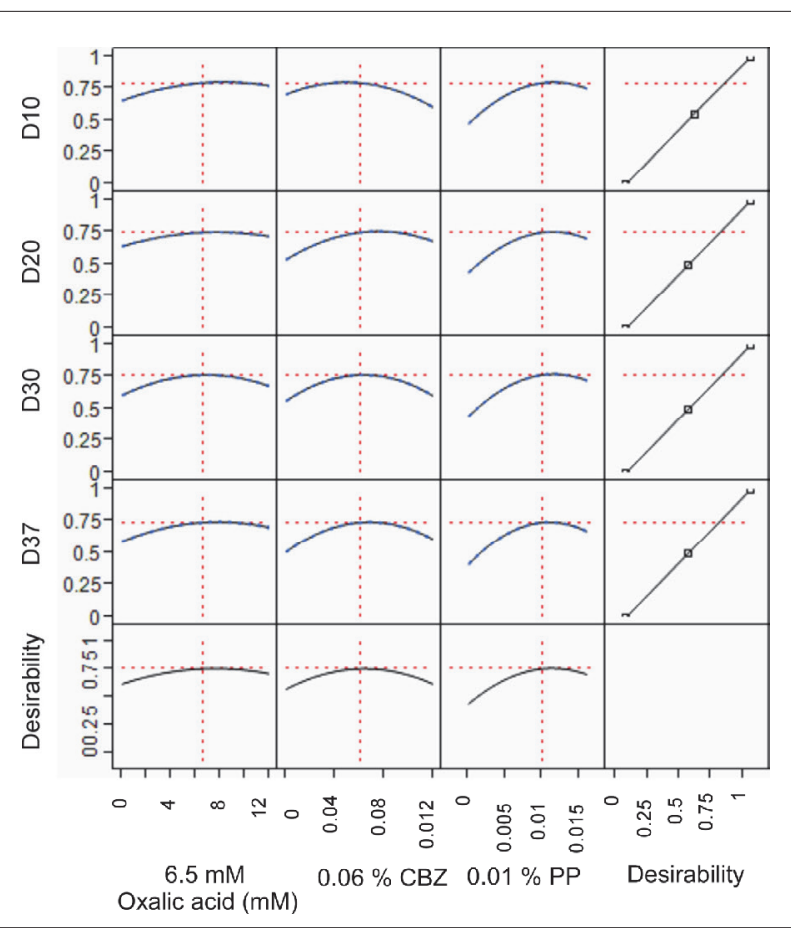

FIGURE 6. Profiler showing the optimal postharvest treatments of longan fruit with fungicide dipping. The optimal values for the postharvest treatment factors were determined by maximizing the higher level desirability function which is a combination of the global desirabilities of the individual storage time point. 
change with varying values of these experimental factors due to their interaction. The last column of graphs shows the desirability functions for the desirabilities of the individual storage time points and how the overall desirability over the whole storage period is composed by maximizing the desirabilities of the individual underlying desirabilities of each individual storage time point. The bottom row of graphs summarizes the dependency of the desirability integrated over the whole storage period on the three experimental main factors. Depending on the market requirements, two different scenarios were considered and represented in respectively Figures 5 and 6. For fruit intended for export to high-standard markets no fungicide treatment is allowed and CBZ was thus set to $0 \%$. The optimal treatment conditions in which the maximum quality was retained were dipping the fruit for $10 \mathrm{~min}$ in a $7 \mathrm{mM}$ oxalic acid solution, draining them, and then packing in a polypropylene bag with a relative perforation area of $0.01 \%$ (Figure 5). For fruit intended for local and regional consumption, where some fungicide residues are still allowed, the optimal treatment conditions were found to be dipping the fruit for $1 \mathrm{~min}$ in a solution of CBZ $0.06 \%$, then for $10 \mathrm{~min}$ in a $6.5 \mathrm{mM}$ oxalic acid solution, draining them, and finally packing in a polypropylene bag with a relative perforation area of $0.01 \%$ (Figure 6 ). This combination gave the best desirability integrated over the whole storage period (Figure 6, bottom row of graphs) and largely coincided with the maximum feasible desirability for each of the individual storage time points (Figure 6, last column of graphs). Appearance of the longan fruit at harvest and after 37 days stored under the optimal condition is presented in Figure S1.

In order to inspect the CBZ residue on the longan fruit, the samples dipped in $0.05 \%$ CBZ solution at day 0 (immediately after dipping in CBZ solution) and after $30 \mathrm{~d}$ of storage were sent to the Center for Inspection and Testing of Plant Protection Drugs in Hanoi, Vietnam. The liquid chromatography mass spectroscopy results showed that the levels of CBZ in the sample at day 0 were 35 times lower than the maximum residue limit of CBZ in food provisions for local consumption which is $1 \mathrm{mg} \mathrm{kg}^{-1}$ (Bo Y Te, 2016). After $30 \mathrm{~d}$, no residue was detected. Hence, from these results it appears that after treating with CBZ, fruit complies with the local safety regulations.

\section{Conclusions}

The current research showed the role of oxalic acid, carbendazim, and relative perforation area of the bag on maintaining the quality of longan during storage. Based on a Box-Behnken experimental design, the classical response surface methodology was extended into a hierarchical approach enabling the optimization of the integral storage period for longan fruit. The optimal postharvest treatment for export fruit was found to be dipping it in oxalic solution of $7 \mathrm{mM}$, and packing it using a $0.01 \%$ relative perforation area, while for fruit intended for local and regional consumption the optimum conditions were dipping in solution of CBZ $0.06 \%$, followed by dipping in oxalic solution of $6.5 \mathrm{mM}$, and packaging using a $0.01 \%$ relative perforation area. Under these conditions, overall fruit quality is expected to retain its quality for $37 \mathrm{~d}$ of storage at $4 \pm 1^{\circ} \mathrm{C}$.

\section{Acknowledgments}

This work was funded by the Flemish Interuniversity Council (VLIR-UOS, Projects No. ZEIN2014Z177 and ZEIN2015PR413). The authors thank the staff and students of Faculty of Food Science and Technology, VNUA, for their kind assistance.

\section{References}

Apai, W., Huntavee, M., and Likhittragulrung, S. (2010). Effects of acid dips on pericarp browning and fruit quality of longan fruit during cold storage. Acta Hortic. 875, 213-221. https://doi.org/10.17660/ ActaHortic.2010.875.26.

Bezerra, M.A., Santelli, R.E., Oliveira, E.P., Villar, L.S., and Escaleira, L.A. (2008). Response surface methodology (RSM) as a tool for optimization in analytical chemistry. Talanta 76, 965-977. https:// doi.org/10.1016/j.talanta.2008.05.019.

Bo Y Te (2016). Quy dinh gioi han toi da du luong thuoc bao ve thuc vat trong thuc pham. Thong tu so 50/2016/TT-BYT (in Vietnamese).

Boonin, P., Whangchai, K., Saengnil, K., and Uthaibutra, J. (2006). Effect of anti-browning substances on peel color and quality of longan fruit cv. Daw during storage. Agri. Sci. J. 37, 144-147.

Chomkitichai, W., Faiyue, B., Rachtanapun, P., Uthaibutra, J., and Saengnil, K. (2014). Enhancement of the antioxidant defense system of post-harvested 'Daw' longan fruit by chlorine dioxide fumigation. Sci. Hortic. (Amsterdam) 178, 138-144. https://doi.org/10.1016/j. scienta.2014.08.016.

Derringer, G., and Suich, R. (1980). Simultaneous optimization of several response variables. J. Qual. Technol. 12, 214-219. https:// doi.org/10.1080/00224065.1980.11980968.

Duan, X.W., Su, X., You, Y., Qu, H., Li, Y., and Jiang, Y. (2007). Effect of nitric oxide on pericarp browning of harvested longan fruit in relation to phenolic metabolism. Food Chem. 104, 571-576. https:// doi.org/10.1016/j.foodchem.2006.12.007.

Duan, X.W., Zhang, H.Y., Zhang, D.D., Sheng, J.F., Lin, H.T., and Jiang, Y.M. (2011). Role of hydroxyl radical in modification of cell wall polysaccharides and aril breakdown during senescence of harvested longan fruit. Food Chem. 128, 203-207. https://doi.org/10.1016/j. foodchem.2011.03.031.

Etienne, A., Génard, M., Lobit, P., Mbeguié-A-Mbéguié, D., and Bugaud, C. (2013). What controls fleshy fruit acidity? A review of malate and citrate accumulation in fruit cells. J. Exp. Bot. 64, 1451-1469. https://doi.org/10.1093/jxb/ert035.

Hallman, G.J. (1999). Ionizing radiation quarantine treatments against tephritid fruit flies. Postharvest Biol. Technol. 16, 93-106. https://doi.org/10.1016/S0925-5214(99)00012-5.

Huang, H.B. (1995). Advances in fruit physiology of the arillate fruit of litchi and longan. Annu. Rev. Hortic. Sci. 1, 107-120.

Jiang, Y.M. (1997). The use of microbial metabolites against postharvest diseases of longan fruit. Int. J. Food Sci. Tech. 32(6), 535-538. https://doi.org/10.1111/j.1365-2621.1997.tb02128.x.

Jiang, Y.M., and Li, Y.B. (2001). Effects of chitosan coating on postharvest life and quality of longan. Food Chem. 73, 139-143. https://doi.org/10.1016/S0308-8146(00)00246-6.

Jiang, Y.M., Zhang, D.C., and Ketsa, S. (2002). Postharvest biology and handling of longan (Dimocarpus longan Lour.) fruit. Postharvest Biol. Technol. 26, 241-252. https://doi.org/10.1016/S09255214(02)00047-9.

Kaewsuksaeng, S., Uthairatanakij, A., and Kanlayanarat, S. (2010). Physiological changes in longan (Dimocarpus longan Lour.) fruit during controlled atmosphere storage. Acta Hortic. 857, 401-404. https://doi.org/10.17660/ActaHortic.2010.857.49.

Khan, A.S., Ahmad, N., Malik, A.U., and Amjad, M. (2012). Cold storage influences the postharvest pericarp browning and quality of litchi. Int. J. Agric. Biol. 14, 389-394.

Koslanund, R., Karunsatitchai, A., and Dejnumbun, W. (2008). Acid dip, a new alternative method to replace $\mathrm{SO}_{2}$ fumigation in longan. J. Agr. Sci. 39, 39-42. 
Li, J., Miao, S., and Jiang, Y. (2009). Changes in quality attributes of longan juice during storage in relation to effects of thermal processing. J. Food Quality 32, 48-57. https://doi.org/10.1111/ j.1745-4557.2008.00235.x.

Liang, H.H., Huang, X.Y., and Ji, Z.L. (1998). Modified atmosphere storage of longan fruit. Chinese J. Trop. Crops 19(2), 49-54.

Lin, H.T., Chen, S.J., Chen, J.Q., and Hong, Q.Z. (2001). Current situation and advances in postharvest storage and transportation technologies of longan fruit. Acta Hortic. 558, 343-351. https://doi. org/10.17660/ActaHortic.2001.558.56.

Lu, R.X., Zhan, X.J., Wu, J.Z., Zhuang, R.F., Huang, W.N., Cai, L.X., and Huang, Z.M. (1992). Studies on storage of longan fruit. Subtrop. Plant Res. Commun. 21, 9-17.

McGuire, R.G. (1998). The response of longan fruit to cold and gamma irradiation treatments for quarantine eradication of exotic pests. J. Hortic. Sci. Biotechnol. 73, 687-690. https://doi.org/10.108 0/14620316.1998.11511034.

Onnop, W.A., Daorueng, S., and Supamontri, P. (1987). Storage of lychee and longan at ambient temperature using hot benomyl treatment and film wrap. National Seminar on Appropriate Postharvest Technology, Chiang Mai, Thailand, p. 205-211.

Saengnil, K., Chumyam, A., Faiyue, B., and Uthaibutra, J. (2014). Use of chlorine dioxide fumigation to alleviate enzymatic browning of harvested 'Daw' longan pericarp during storage under ambient conditions. Postharvest Biol. Technol. 91, 49-56. https://doi. org/10.1016/j.postharvbio.2013.12.016.

Sardsud, U., Chaiwangsri, T., Sardsud, V., and Sittigul, C. (1994). Effects of plant extracts on the in vitro and in vivo development longan fruit pathogens. Development of Postharvest Handling Technology for Tropical Tree Fruit (Canberra, Australia: ACIAR), p. 60-62.

Sardsud, V., Sardsud, U., Chantrasri, P., and Pasatketkorn, S. (2003). Alternative postharvest treatments in longan fruit for replacement of sulfur dioxide fumigation. J. Agr. Sci. 33(Suppl.), 243-246.

Sardsud, V., Sittigul, C., Chaiwangsri, T., and Sardsud, U. (1994). Effects of post-fumigation washing treatments and storage temperature on disease development in fresh longan. Development of Postharvest Handling Technology for Tropical Tree Fruit (Canberra, Australia: ACIAR), p. 77-79.

Shi, S., Wang, W., Liu, L., Wuc, S., Wei, Y., and Li, W. (2013). Effect of chitosan/nano-silica coating on the physicochemical characteristics of longan fruit under ambient temperature. J. Food Eng. 118, 125131. https://doi.org/10.1016/j.jfoodeng.2013.03.029.

Singleton, V.L., and Rossi, J.A.J. (1965). Colorimetry of total phenolics with phosphomolybdic-phosphotungstic acid reagents. Am. J. Enol. Vitic. 16, 144-158.

Siracusa, V., Blanco, I., Romani, S., Tylewicz, U., and Dalla Rosa, M. (2012). Gas permeability and thermal behavior of polypropylene films used for packaging minimally processed fresh-cut potatoes: a case study. J. Food Sci. 77(10), 264-272. https://doi.org/10.1111/ j.1750-3841.2012.02905.x.

Sivakumar, D., Arrebola, E., and Korsten, L. (2008). Postharvest decay control and quality retention in litchi (cv. McLean's Red) by combined application of modified atmosphere packaging and antimicrobial agents. Crop Prot. 27, 1208-1214. https://doi.org/10.1016/j. cropro.2008.03.002.

Son, S.M., Moon, K.D., and Lee, C.Y. (2001). Inhibitory effects of various antibrowning agents on apple slices. Food Chem. 73, 23-30. https://doi.org/10.1016/S0308-8146(00)00274-0.

Suttirak, W., and Manurakchinakorn, S. (2010). Potential application of ascorbic acid, citric acid and oxalic acid for browning inhibition in fresh-cut fruit and vegetables. Walailak J. Sci. Technol. 7, 5-14.
Taiz, L., and Zeiger, E. (2006). Plant Physiology, $4^{\text {th }}$ ed. (Sunderland, Massachusetts, USA: Sinauer Associates), 700 pp.

Thavong, P., Archbold, D.D., Pankasemsuk, T., and Koslanund, R. (2010). Effect of hexanal vapour on longan fruit decay, quality and phenolic metabolism during cold storage. Int. J. Food Sci. Tech. 45, 2313-2320. https://doi.org/10.1111/j.1365-2621.2010.02401.x.

Tian, S.P., Xu, Y., Jiang, A.L., and Gong, Q.Q. (2002). Physiological and quality responses of longan fruit to high $\mathrm{O}_{2}$ or high $\mathrm{CO}_{2}$ atmospheres in storage. Postharvest Biol. Technol. 24, 335-340. https://doi. org/10.1016/S0925-5214(01)00153-3.

Tongdee, S.C. (1994). Sulfur dioxide fumigation in postharvest handling of fresh longan and lychee for export. International Conference Postharvest Handling of Tropical Fruit, Chang Mai, Thailand, 19-23 July, 1993, p. 186-195.

Tran The Tuc (2004). Cay nhan va ky thuat trong. Nha xuat ban Lao Dong - Xa Hoi. 200 pp. (in Vietnamese).

Tran Thi Dinh, and Nguyen Thi Quyen (2015). Anh huong cua xu ly sau thu hoach den su bien doi chat luong cua nhan Huong Chi trong qua trinh bao quan lanh. Tap chi Khoa hoc va phat trien $8,1464-$ 1473 (in Vietnamese).

Whangchai, K., Saengnil, K., and Uthaibutra, J. (2006). Effects of ozone in combination with some organic acids on the control of postharvest decay and pericarp browning of longan fruit. Crop Prot. 25, 821-825. https://doi.org/10.1016/j.cropro.2005.11.003.

Xu, X.D., Huang, J.S., Zheng, S.Q., Xu, J.H., and Liu, H.Y. (1999). Effect of smouldering sulphur on browning of picked longan fruit and desulphurizatic effect. Fujian J. Agric. Sci. 14, 34-39.

Yoruk, R., and Marshall, M.R. (2003). A survey on the potential mode of inhibition for oxalic acid on polyphenol oxidase. J. Food Biochem. 27, 361-422. https://doi.org/10.1111/j.1745-4514.2003. tb00289.x.

Zhou, Y., Ji, Z.L., and Lin, W.Z. (1997). The effect of different packaging and different fungicide and sulphur treatment on longan fruit storage. South China Fruit 26, 24-27.

Zhuang, Y.M., Ke, K.W., Zeng, W.X., and Pan, X.W. (1998). Tropical and Subtropical Fruit in China (Beijing, China: China Agriculture Press), p. 103-107.

Received: Jul. 7, 2017

Accepted: Apr. 18, 2018

Addresses of authors:

Dinh T. Tran ${ }^{1, *}$, Maarten Hertog ${ }^{3}$ and Bart M. Nicolaï ${ }^{2,3}$

${ }^{1}$ Faculty of Food Science and Technology, Vietnam National University of Agriculture, Trauquy, Gialam, Hanoi, Vietnam

${ }^{2}$ Flanders Centre of Postharvest Technology, Willem de Croylaan 42, B-3001 Leuven, Belgium

${ }^{3}$ BIOSYST-MeBioS, Faculty of Bioscience Engineering, KU Leuven, Willem de Croylaan 42, B-3001 Leuven,

Belgium

* Corresponding author; E-mail: ttdinh@vnua.edu.vn Tel.: +84 626177 18; Fax: +84 438276554 
TABLE S1. Coefficients of the second order models for each response variable at different storage periods.

\begin{tabular}{|c|c|c|c|c|c|c|c|}
\hline Components & $\begin{array}{l}\text { Acidity } \\
\left(g^{-1}\right)\end{array}$ & $\begin{array}{l}\text { SSC } \\
(\%)\end{array}$ & $\begin{array}{l}\text { Hue } \\
\left({ }^{\circ}\right)\end{array}$ & $\begin{array}{c}\text { Total } \\
\text { phenolics } \\
(\% \text { DW })\end{array}$ & $\begin{array}{c}\text { Disease } \\
\text { index }\end{array}$ & $\begin{array}{l}\text { Browning } \\
\text { index }\end{array}$ & $\begin{array}{c}\text { Weight loss } \\
(\%)\end{array}$ \\
\hline \multicolumn{8}{|l|}{ After $10 d$} \\
\hline Intercept & 0.6375 & 16.91 & 80.76 & 8.47 & 1.15 & 1.8 & 0.19 \\
\hline Oxalic acid $\left(X_{1}\right)$ & 0.002 & 0.014 & $0.04^{*}$ & 0.03 & $-0.007^{\star}$ & $0.001^{*}$ & $-0.001^{*}$ \\
\hline $\operatorname{CBZ}\left(X_{2}\right)$ & -0.18 & 1.33 & $-3.95^{*}$ & $-2.03^{*}$ & -2.29 & $-0.17^{\star}$ & $0.39^{*}$ \\
\hline Relative perforation area $\left(X_{3}\right)$ & 1.29 & 8.59 & 179.4 & 43.6 & $8 \mathrm{E}-15^{*}$ & -99.5 & -6.91 \\
\hline$X_{1}^{2}$ & -0.001 & $-0.001^{*}$ & $0.01^{*}$ & $-0.004^{*}$ & $-0.001^{*}$ & 0.02 & $-0.0003^{*}$ \\
\hline$X_{1} \times X_{2}$ & $0.02^{*}$ & $-0.1^{*}$ & $1.97^{*}$ & 1.31 & $0.28^{*}$ & $0.3^{*}$ & $0.07^{*}$ \\
\hline$X_{2}^{2}$ & $-2.75^{\star}$ & $-10.3^{*}$ & $-94.9^{*}$ & -210.2 & $45.8^{*}$ & -140 & 25.6 \\
\hline$X_{1} \times X_{3}$ & $0.23^{*}$ & $0.1^{*}$ & 28.77 & $-1.65^{\star}$ & $-7 \mathrm{E}-17^{\star}$ & $-2.08^{*}$ & $0.16^{*}$ \\
\hline$X_{2} \times X_{3}$ & $12.5^{\star}$ & $-62.5^{*}$ & $758^{*}$ & $-317^{*}$ & $-8 \mathrm{E}-16^{*}$ & $-479^{*}$ & $33.5^{*}$ \\
\hline$X_{3}^{2}$ & $-166^{*}$ & $-1117^{*}$ & $-3601^{*}$ & -8184 & $683^{*}$ & 1289 & 616 \\
\hline Model ( $p$-value) & $<0.0001$ & $<0.0001$ & $<0.0001$ & $<0.0001$ & 0.26 & $<0.0001$ & $<0.0001$ \\
\hline \multicolumn{8}{|l|}{ After $20 d$} \\
\hline Intercept & 0.51 & 16.34 & 77.19 & 7.28 & 1.37 & 2.22 & 0.19 \\
\hline Oxalic acid $\left(X_{1}\right)$ & 0.002 & 0.013 & 0.14 & 0.06 & $-0.0015^{*}$ & $0.01^{*}$ & $-0.0007^{*}$ \\
\hline $\operatorname{CBZ}\left(X_{2}\right)$ & 0.41 & 2.83 & $20.3^{*}$ & 2.93 & -6.15 & $1.56^{*}$ & $-0.11^{*}$ \\
\hline Relative perforation area $\left(X_{3}\right)$ & 2.54 & 17.18 & 125.2 & 53.99 & $-6.72^{*}$ & -151.2 & $-1.73^{*}$ \\
\hline$X_{1}^{2}$ & -0.001 & $5 \mathrm{E}-5^{*}$ & $-0.005^{*}$ & $0.002^{*}$ & $0.005^{*}$ & 0.02 & $0.001^{*}$ \\
\hline$X_{1} \times X_{2}$ & $2 \mathrm{E}-18^{*}$ & 0.33 & $0.05^{*}$ & 0.69 & $-0.63^{*}$ & $0.4^{*}$ & $-0.05^{\star}$ \\
\hline$X_{2}^{2}$ & -12.3 & -36.11 & -347 & $-26.4^{*}$ & $88.3^{*}$ & $102^{*}$ & $14.46^{*}$ \\
\hline$X_{1} \times X_{3}$ & $0.15^{\star}$ & $1.04^{*}$ & 3.61 & 2.88 & $0.39^{*}$ & $-1.45^{\star}$ & $0.7^{*}$ \\
\hline$X_{2} \times X_{3}$ & 54.7 & $166.7^{*}$ & 2315 & -788 & $229^{*}$ & $-393^{*}$ & -221 \\
\hline$X_{3}^{2}$ & $203.5^{*}$ & -2322 & $-28,479$ & -7632 & $820^{*}$ & 22,871 & 2674 \\
\hline Model (p-value) & $<0.0001$ & $<0.0001$ & $<0.0001$ & $<0.0001$ & 0.013 & $<0.0001$ & $<0.0001$ \\
\hline \multicolumn{8}{|l|}{ After $30 \mathrm{~d}$} \\
\hline Intercept & 0.49 & 16.07 & 74.78 & 6.78 & 1.98 & 3.36 & 0.4 \\
\hline Oxalic acid $\left(X_{1}\right)$ & 0.003 & 0.01 & 0.17 & 0.04 & 0.01 & 0.04 & -0.006 \\
\hline $\operatorname{CBZ}\left(X_{2}\right)$ & $0.11^{*}$ & 2.58 & $4.61^{*}$ & $1.61^{*}$ & -9.98 & -8.6 & -0.67 \\
\hline Relative perforation area $\left(X_{3}\right)$ & $0.51^{*}$ & 21.35 & 195.7 & 50.5 & $-11.9^{*}$ & -138.9 & $-2.01^{*}$ \\
\hline$X_{1}^{2}$ & $-0.004^{*}$ & $0.0008^{*}$ & -0.05 & $-0.002^{*}$ & $0.007^{\star}$ & $0.002^{*}$ & 0.003 \\
\hline$X_{1} \times X_{2}$ & $-0.01^{*}$ & $0.1^{*}$ & $-1.16^{*}$ & 1.71 & $-0.2^{*}$ & $0.7^{*}$ & 0.26 \\
\hline$X_{2}^{2}$ & -7.25 & -55.5 & $-185^{*}$ & $-11.1^{*}$ & 141.6 & 388.1 & 24.83 \\
\hline$X_{1} \times X_{3}$ & 0.55 & $-0.2^{*}$ & $11.96^{*}$ & $-0.18^{*}$ & $2.47^{*}$ & $-5.56^{*}$ & $-0.62^{*}$ \\
\hline$X_{2} \times X_{3}$ & $-18.75^{\star}$ & $-3 E-13^{*}$ & $897^{*}$ & -742 & $602.1^{*}$ & -800 & $21.26^{*}$ \\
\hline$X_{3}^{2}$ & $9.77^{\star}$ & -3732 & -23658 & -7790 & $2094^{*}$ & 23999 & $625.8^{*}$ \\
\hline Model ( $p$-value) & 0.021 & $<0.0001$ & $<0.0001$ & $<0.0001$ & 0.0006 & $<0.0001$ & $<0.0001$ \\
\hline \multicolumn{8}{|l|}{ After $37 d$} \\
\hline Intercept & 0.44 & 15.6 & 70.5 & 6.37 & 2.71 & 5.51 & 0.49 \\
\hline Oxalic acid $\left(X_{1}\right)$ & 0.003 & 0.02 & 0.26 & 0.03 & 0.003 & -0.08 & -0.007 \\
\hline $\operatorname{CBZ}\left(X_{2}\right)$ & $0.11^{*}$ & 3.17 & 20.06 & 3.14 & -17.7 & -7.58 & $-0.49^{*}$ \\
\hline Relative perforation area $\left(X_{3}\right)$ & $-0.64^{*}$ & 25.83 & 310.6 & 41.15 & $-5.87^{\star}$ & -122 & $3.14^{*}$ \\
\hline$X_{1}^{2}$ & -0.001 & $0.0004^{*}$ & -0.07 & 0.003 & 0.01 & $0.004^{*}$ & $0.002^{*}$ \\
\hline$X_{1} \times X_{2}$ & $-0.03^{*}$ & $-0.2^{*}$ & $-1.23^{*}$ & 0.36 & $0.14^{*}$ & $-0.04^{*}$ & 0.36 \\
\hline$X_{2}^{2}$ & -4.96 & -79.35 & $-215.8^{*}$ & -40.9 & 362.1 & 239.7 & 21.01 \\
\hline$X_{1} \times X_{3}$ & 0.73 & $-1.04^{*}$ & $3.55^{*}$ & -6.63 & $-1.87^{*}$ & $-3.97^{*}$ & $-0.89^{*}$ \\
\hline$X_{2} \times X_{3}$ & -46.9 & $166.7^{*}$ & $721.4^{*}$ & 269.7 & $512^{*}$ & -854.2 & $-80.2^{*}$ \\
\hline$X_{3}{ }^{2}$ & 500 & -3757 & $-34,030$ & $-12,767$ & 5699 & 13,300 & 2192 \\
\hline Model (p-value) & $<0.0001$ & $<0.0001$ & $<0.0001$ & $<0.0001$ & $<0.0001$ & $<0.0001$ & $<0.0001$ \\
\hline
\end{tabular}




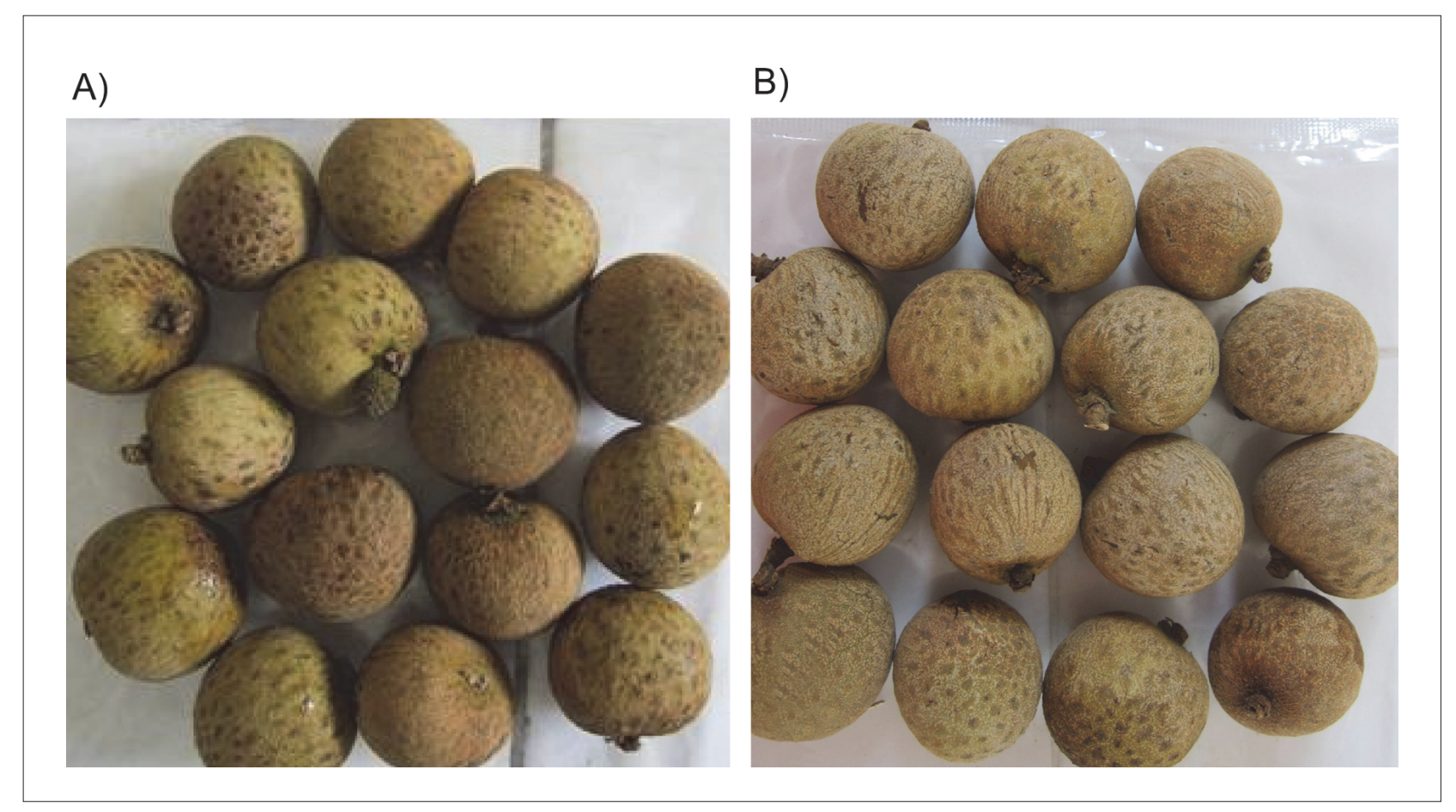

FIGURE 1S. Appearance of the longan fruit A) at day 0 and B) after 37 days stored under the optimal condition. 